\title{
A trehalose 6-phosphate synthase gene of the hemocytes of the blue crab, Callinectes sapidus: cloning, the expression, its enzyme activity and relationship to hemolymph trehalose levels J Sook Chung
}

Address: Center of Marine Biotechnology, University of Maryland Biotechnology Institute, 701 E. Pratt Street, Columbus Center, Suite 236. Baltimore, MD 21202, USA

Email: J Sook Chung - chung@comb.umbi.umd.edu

Published: 12 December 2008

Saline Systems 2008, 4:18 doi:10.1 186/1746-1448-4-18

This article is available from: http://www.salinesystems.org/content/4/1/18

(c) 2008 Chung; licensee BioMed Central Ltd.

This is an Open Access article distributed under the terms of the Creative Commons Attribution License (http://creativecommons.org/licenses/by/2.0), which permits unrestricted use, distribution, and reproduction in any medium, provided the original work is properly cited.
Received: 26 August 2008

Accepted: 12 December 2008

\begin{abstract}
Trehalose in ectoderms functions in energy metabolism and protection in extreme environmental conditions. We structurally characterized trehalose 6-phosphate synthase (TPS) from hemocytes of the blue crab, Callinectes sapidus. C. sapidus Hemo TPS (CasHemoTPS), like insect TPS, encodes both TPS and trehalose phosphate phosphatase domains. Trehalose seems to be a major sugar, as it shows higher levels than does glucose in hemocytes and hemolymph. Increases in HemoTPS expression, TPS enzyme activity in hemocytes, and hemolymph trehalose levels were determined $24 \mathrm{~h}$ after lipopolysaccharide challenge, suggesting that both TPS and TPP domains of CasHemoTPS are active and functional. The TPS gene has a wide tissue distribution in $C$. sapidus, suggesting multiple biosynthetic sites. A correlation between TPS activity in hemocytes and hemolymph trehalose levels was found during the molt cycle. The current study provides the first evidence of presence of trehalose in hemocytes and TPS in tissues of $C$. sapidus and implicates its functional role in energy metabolism and physiological adaptation.
\end{abstract}

\section{Background}

Trehalose, a non-reducing disaccharide is a primary energy source in prokaryotes, yeasts, plants, and invertebrates. The accumulation of trehalose in anhydrobioses of artemia, nematodes, and chironomids [1-3] implies a role in physiological and biochemical adaptations in extreme environmental conditions.

In insects, trehalose is the major hemolymph sugar that is exclusively synthesized in the fat body in which hypertrehalosemic hormone (HTH) positively regulates its production. In addition, flight, feeding, and parasitic infections in insects have been shown to produce hypertrehalosemia, i.e. an increase in trehalose in hemolymph [4-6]. These findings further support trehalose as an energy source and its involvement in physiological adaptation in insects.

Trehalose 6-phosphate synthase (TPS) is noted in insects as a fused gene that codes two functional domains in tandem: TPS, a homolog of Ost A of Escherichia coli, and trehalose 6-phophate phosphatase (TPP), a homolog of Ost B of E. coli. Drosophila TPS introduced into human HEK-293 cells increased hypoxia tolerance by which elevated trehalose reduced protein aggregation under hypoxia $[2,7]$. This result indicates two domains of TPS and TPP are active. However, a relationship between the level of TPS expression and TPS enzyme activity resulting in the increase in trehalose production has not been described in insects. 
In contrast to hypertrehalosemic response under stress and during flight activity in insects, the increase in glucose level in hemolymph (i.e. hyperglycemia) of crustaceans has been described during their initial physiological adaptation to stressful environments [8-15]. Lipopolysaccharide (LPS) injection, an accepted method for mimicking a pathogen infection, also induced hyperglycemia through modulating the level of crustacean hyperglycemic hormone [13]. The glycogen present in many crustacean tissues, including hemocytes, is tacitly accepted as the source of this hyperglycemia. Previous reports of the involvement of trehalose in osmoregulation and cold adaptation in crustaceans $[16,17]$ and the ubiquitous abundance of trehalose in insect hemolymph as an energy source and its protective roles under stress emphasize the importance of this molecule in invertebrates. Therefore, we investigated the presence of TPS gene and trehalose in the blue crab, Callinectes sapidus, the population of which has been drastically declining in the Chesapeake Bay [18], in order to better understand the role of this sugar in energy metabolism during molt cycles and physiological adaptation under stressful conditions. Particularly, in an attempt to define an adaptive role of trehalose in a different physiological status of $C$. sapidus, we challenged animals with LPS that generally induced the response of a pathogen infection as well as the stress response of hyperglycemia in crustaceans $[13,15]$. We demonstrated hypertrehalosemic and hyperglycemic responses by LPS injection into the animal that was accompanied by increases in TPS expression and TPS enzyme activity in hemocytes. A relationship between TPS activity in hemocytes and the level of hemolymph trehalose during a molt cycle was established.

\section{Results and discussion \\ Phylogenetic tree analysis of multiple sequence alignments of TPS gene}

CasHemoTPS (GenBank accession no. EU679406) consisting of 755 amino acid encodes a putative TPS and a TPP domain in tandem. Phylogenic tree analysis of multiple sequence alignments of TPS gene revealed that C. sapidus Hemocytes TPS (CasHemoTPS) is closely related to those of insects, forming a separate group from E. coli, Saccharomyces cerevisae, and Ulva prolifera (Fig. 1) [19]. The TPS gene in arthropods appears to be a fused gene of a homolog of Ost A and Ost B in E. coli.

\section{Spatial distribution of TPS gene expression in various tissues of $C$. sapidus}

cDNAs of various tissues prepared from an adult male and female C. sapidus were tested for the TPS expression. As shown in Fig. 2, TPS expression was ubiquitous in all the tissues of both sexes of adult crabs, indicating that all these tissues could produce trehalose. It appears that multiple isoforms of TPS genes are present in tissues of the blue crab, as three of these, coding both TPS and TPP, have already been identified (unpublished observation). This wide distribution of TPS gene in crab tissues is surprising in contrast to what has been described in insects. In insects, the fat body is known as the exclusive biosynthetic site of trehalose $[4,20,21]$. After synthesis in the fat body, trehalose is released into hemolymph and serves as a major hemolymph sugar for energy required during flight.

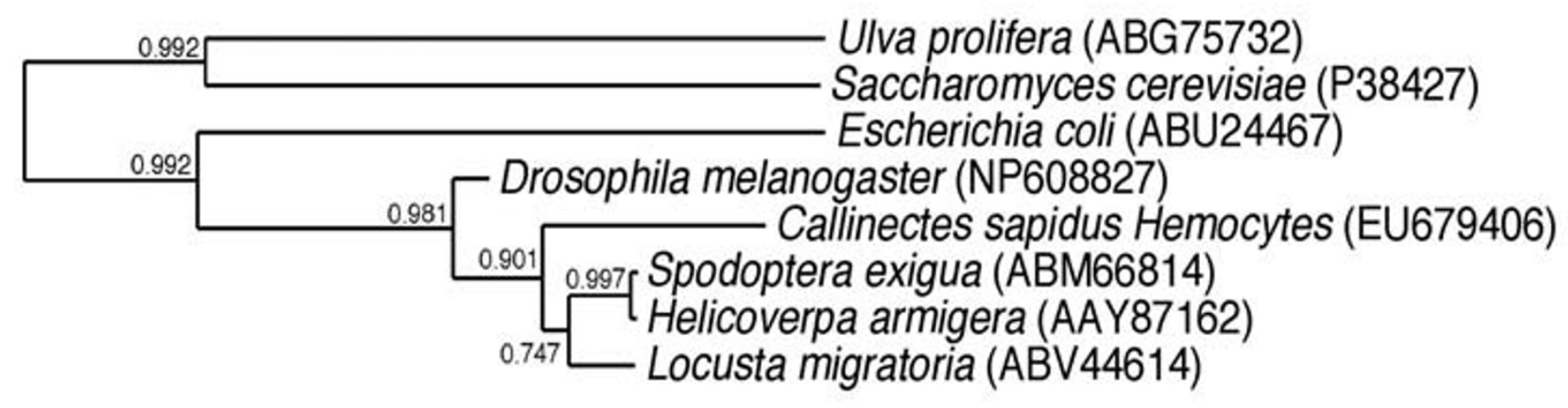

\section{4}

\section{Figure I}

Phylogenetic tree analysis of deduced amino acids of TPS including Callinectes sapidus hemocytes (EU679406), Spodoptera exigua (ABM668I4), Helicoverpa armigera (AAY87I62), Locusta migratoria (ABV446I4), Drosophila melanogaster ( coli (ABU24467), Saccharomyces cerevisiae (P38427), and Ulva prolifera (ABG75732). The neighbor-joining tree was constructed and bootstrapped ( 1000 iterations) using Robust Phylogenetic Analysis for the Non-Specialist [19]. Bootstrap values are noted on the branch and the scale bar $(=0.4)$ represents fixed mutations per amino acid position. 
(A) Male

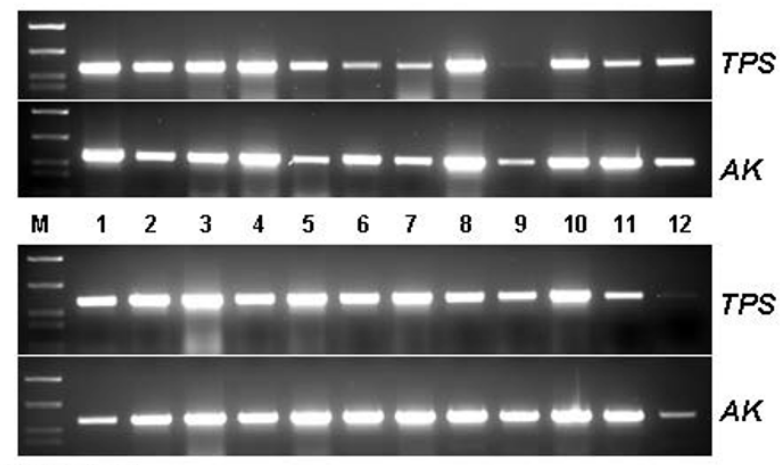

(B) Female

\section{Figure 2}

Spatial distribution of TPS gene in cDNAs of various tissues of adult male and female of $C$. sapidus. TPSF2 and TPSR I primers as listed in Table I was used for PCR amplification with $12.5 \mathrm{ng}$ of total RNA equivalent of each tissue. Arginine kinase served for a reference gene. Lane I: eyestalk, 2: brain, 3: thoracic ganglion, 4: antennal gland, 5: gill, 6: hindgut, 7: heart, 8: chelae muscle, 9: hypodermis, 10: testis $(A)$ and ovary (B), I I: hepatopancreas, and I2: Y-organ.

\section{The effect of LPS on the expression of TPS, TPS activity and trehalose levels}

Animals were challenged by the injection of $1 \mu \mathrm{g}$ LPS to test the response of trehalose. The resting level of trehalose in hemocytes was higher than in hemolymph: $3.5 \pm$ $0.3 \mathrm{mg}(\mathrm{n}=6)$ (Fig. $3 \mathrm{~A})$ and $1.1 \pm 0.1 \mathrm{mg} / \mathrm{ml}(\mathrm{n}=6)$, respectively. In contrast, the level of glucose was higher in hemolymph than in hemocytes: $180 \pm 14.6 \mu \mathrm{g} / \mathrm{ml}(\mathrm{n}=6)$ and $70 \pm 10 \mu \mathrm{g} / \mathrm{mg}$ protein in hemocyte extracts $(\mathrm{n}=6)$, respectively (Fig. 3B). Overall, the concentration of trehalose was higher than glucose in both hemolymph and hemocytes: 6 and 50 fold, respectively, suggesting that trehalose is a major sugar in crab hemolymph as in insects $[4,21]$. The intracellular level of trehalose was increased $\sim 2.5$ fold in response to the LPS challenge, while a modest 1.5 fold elevation of glucose was found. LPS injection after $24 \mathrm{~h}$ did not cause general hypertrehalosemia or hyperglycemia in hemolymph in C. sapidus, although it was reported that a much higher dose of LPS induced hyperglycemia after $2 \mathrm{~h}$ in other crustacean species $[13,15]$. LPS induced a significant 2.5 fold increase in HemoTPS $m R N A$, a three fold increment of TPS activity, compared to those of the controls (Figs. 3C and 3D). This could be responsible for the increase in trehalose levels in Fig. 3A. A slight change (130\%) in the level of trehalase (Treh) mRNA that breaks down trehalose into two glucose molecules is responsible for the modest rise ( 1.5 fold) in intracellular glucose. The basal level of TPS mRNA in hemocytes was $\sim 100$ fold less than that of Treh.
Our result demonstrates that hemocytes possess TSP and Treh for the synthesis and metabolism of trehalose. More importantly, they modulate cellular trehalose levels for physiological and biochemical adaptation under LPS challenge, through the dynamic regulation of the expression of TPS and TPS enzyme activity. Furthermore, our data indicate that $C$. sapidus expresses TPS in multiple tissues, in contrast to insects where the fat body is considered the exclusive biosynthesis site of this sugar. Considering trehalose is the major blood sugar, it is also likely to be involved in crustacean hyperglycemia. We anticipate its ubiquitous presence in most if not all crustacean hemolymph with similar functions as those found in insects.

\section{Levels of TPS activity in hemocytes and trehalose in hemolymph during a molt cycle}

Concentrations of trehalose in hemolymph of C. sapidus showed a bimodal pattern that exhibited two peaks during molt cycle, at early ecdysis and post ecdysis $\mathrm{C}_{1-3}$ (Fig. 4). The lowest level of trehalose $(0.65 \pm 0.05 \mathrm{mg} / \mathrm{ml}$ hemolymph, $\mathrm{n}=8$ ) was measured at stage A during and after the occurrence of the largest water intake occurred $[22,23]$. The fluctuation of TPS activity in hemocytes was also noted during the molt cycle from the lowest at intermolt to the highest at postmolt stage B: $0.3 \pm 0.08 \mu \mathrm{mol} /$ $\mathrm{h} / \mathrm{mg}$ protein in hemocyte extracts $(\mathrm{n}=12)$ and $1.98 \pm$ $0.74 \mu \mathrm{mol} / \mathrm{h} / \mathrm{mg}$ protein in hemocyte extracts $(\mathrm{n}=7)$, respectively. TPP enzyme activity of HemoTPS was determined only at intermolt by measuring $[\mathrm{Pi}]$ in the same samples that were prepared for TPS activity. The activity of TPP was slightly high: $0.78 \pm 0.41 \mu \mathrm{mol}[\mathrm{Pi}] / \mathrm{h} / \mathrm{mg}$ protein in hemocyte extracts $(n=5)$, however, this value was not significantly different from that of TPS activity. In general, TPS activity was elevated at premolt and peaked at stage B, which correlates with the highest concentration of trehalose noted at stage $\mathrm{C}_{1-3}$. The level of trehalose and TPS activity at the postmolt stage imply a possible involvement of this sugar in chitin synthesis, as found in insects [24]. Chitin synthesis is required for cuticle hardening and the calcification process in the exoskeleton of animals after ecdysis.

\section{Conclusion}

We isolated, for the first time in crustaceans, the cDNA sequence of the TPS gene coding functional and active domains of TPS and TPP in hemocytes of C. sapidus where its expression was widespread in most tissues. LPS injection into animals, mimicking the induction of internal stress, stimulated the expression and enzyme activity of TPS in hemocytes, resulting in the increase in intracellular trehalose in hemocytes. Our results provide evidence of the presence and a possible adaptive function of trehalose in energy metabolism and stress response of decapod crustaceans. 

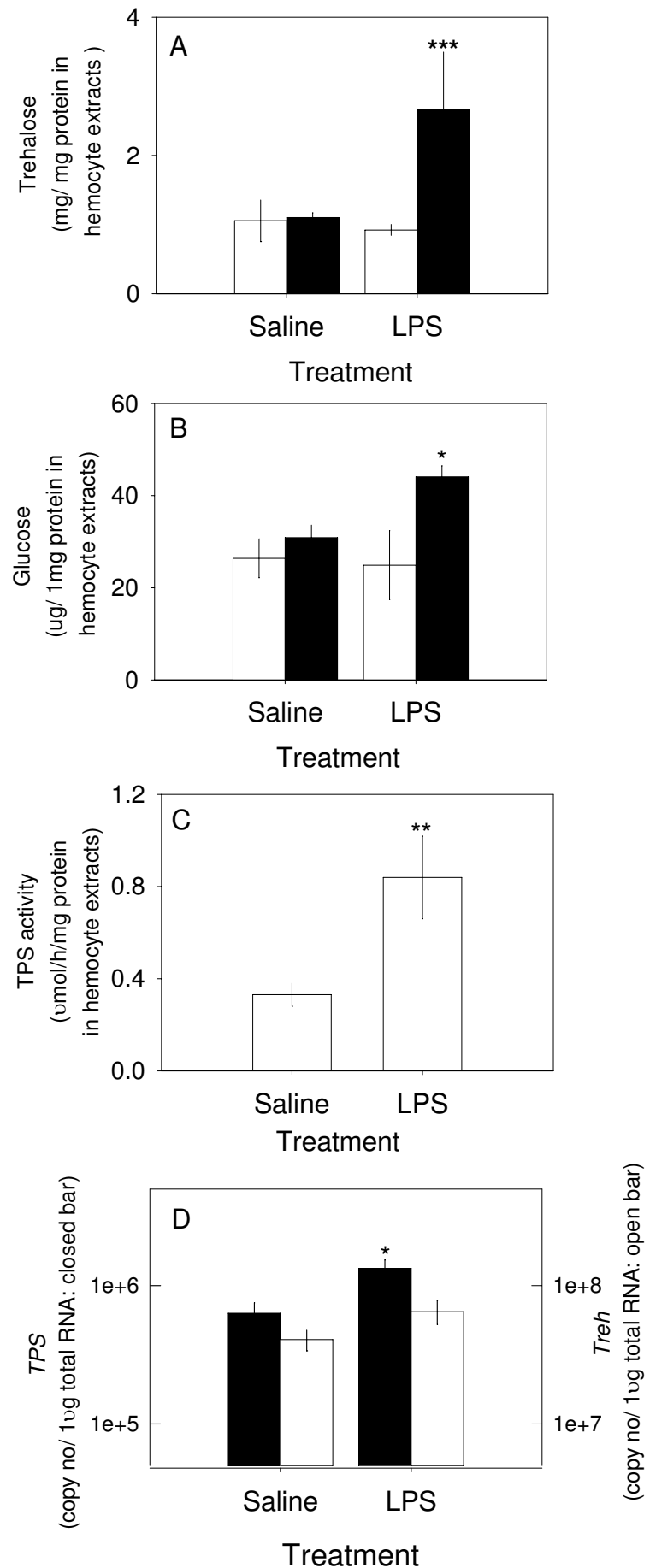

Figure 3

The effects of LPS injection after $24 \mathrm{~h}$ on the levels of intracellular glucose, trehalose, TPS enzyme activity, and the expressions of TPS and Treh in hemocytes. A) Trehalose: open bar at $\mathrm{t}=0 \mathrm{~h}$, solid bar at $24 \mathrm{~h}$; B) Glucose: open bar at $\mathrm{t}=0 \mathrm{~h}$, solid bar at $24 \mathrm{~h}$; C) TPS enzyme activity at $24 \mathrm{~h}$; and D) expressions of TPS and Treh at $24 \mathrm{~h}$ : solid bar = TPS; open bar = Treh. Data is presented as mean \pm I SE $(n=5-8)$ of trehalose in $\mathrm{mg} / \mathrm{mg}$ protein in hemocyte extracts, of glucose in $\mu \mathrm{g} / \mathrm{mg}$ protein in hemocyte extracts, of TPS enzyme activity in $\mu \mathrm{mol} / \mathrm{h} / \mathrm{mg}$ protein in hemocyte extracts and TPS and Treh expressions in copy number/ $\mu \mathrm{g}$ total RNA. Statistical significance at $\mathrm{P}<0.05=*$, at $\mathrm{P}<0.05=* *$, at $\mathrm{P}<0.001=* * *$. 


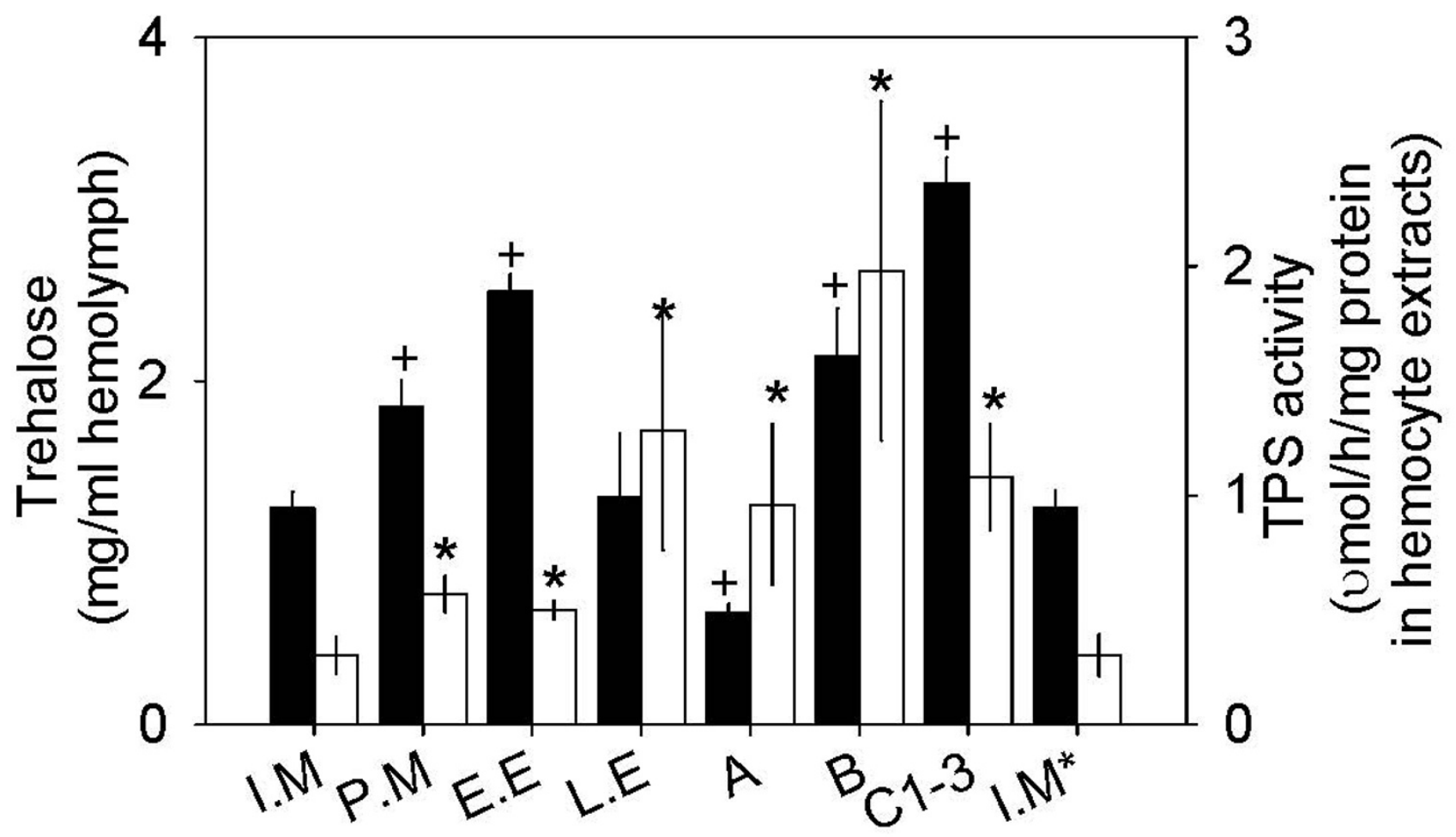

\section{Molt stage}

\section{Figure 4}

Changes in the levels of trehalose in hemolymph and TPS activity in hemocytes during molt cycle. Data is presented as mean \pm I SE $(n=8-15)$ of trehalose in $\mathrm{mg} / \mathrm{ml}$ hemolymph (solid bar) and of TPS enzyme in $\mu \mathrm{mol} / \mathrm{h} / \mathrm{mg}$ protein in hemocyte extracts (open bar). Statistical significances at $\mathrm{P}<0.05$ marked as + (trehalose) or * (TPS activity) were determined using Student's $t$ test by comparing the values at intermolt stage with each different molt stage. I.M = intermolt, $P . M=$ premolt, E.E = early ecdysis, L.E = late ecdysis, $A=$ within $3 \mathrm{~h}$ after ecdysis, $\mathrm{B}=\mathrm{I}-2$ days after ecdysis, $C_{1-3}=3-7$ days after ecdysis, and I.M* $=$ same as I.M.

\section{Materials and methods \\ Animals}

Juvenile blue crabs, C. sapidus (20-30 mm carapace width), were received from the blue crab hatchery in the Aquaculture Research Center, Center of Marine Biotechnology (University of Maryland Biotechnology Institute, Baltimore, MD) and reared as described [25].

\section{5', 3' RACEs of C. sapidus TPS gene}

Hemocytes were harvested from $1 \mathrm{ml}$ hemolymph withdrawn in a sterilized marine anticoagulant (filtered through $0.22 \mu \mathrm{m}$ membrane) at 1:1 ratio and immediately spun at $800 \mathrm{~g}$ for $10 \mathrm{~min} 4{ }^{\circ} \mathrm{C}$. After discarding the plasma, the pelleted cells were washed once in $100 \mu \mathrm{l}$ of anticoagulant and re-centrifuged as above. The washed hemocytes were homogenized and total RNA extraction and quantification were carried out by following the pro- cedures as described [26]. Degenerate primers of TPS were generated based on the conserved region of insect genes listed in GenBank using a multiple alignment program, CLUSTALW http://www.genome.jp).

The synthesis of 3' RACE cDNA of total RNA of hemocytes was carried out using GeneRacer ${ }^{\mathrm{TM}}$ (Invitrogen), while 5' RACE cDNAs was produced using SMART cDNA synthesis kit (BD Biosciences). Touchdown PCR was employed for initial amplification of TPS: dF1 (5'TTYGAYTCYTAYTA YAAYGG3') and dR1 (5'TCDCCRGCDCCRGCRAAD GG3'). The cDNA was amplified with Advantage Taq polymerase (BD Biosciences) at the following PCR conditions: after initial denaturation for $2.5 \mathrm{~min}$ at $94^{\circ} \mathrm{C}, 3$ cycles each step at annealing temperatures: $47^{\circ} \mathrm{C}, 45^{\circ} \mathrm{C}$, and $43^{\circ} \mathrm{C}$ and the final step at $48^{\circ} \mathrm{C}$ for 25 cycles. The final amplification was achieved at annealing temperature 
$48^{\circ} \mathrm{C}$. The touchdown PCR products served as templates for the nested PCR of TPS with a primer combination of dF2 (5' TTYTGGCCNYTNTTYCAYTCYATGCC $3^{\prime}$ ) and dR2 (5'ATYT GRCARGCSACRAAYTC3') at $55^{\circ} \mathrm{C}$ annealing temperature. For the TPS gene, the cDNA from hemocytes produced a band with an expected size of $900 \mathrm{bp}$. The cloning and sequencing procedures were as stated [27]. Based on the obtained C. sapidus sequences of TSP, the following gene specific primers (listed in table 1 ) were made for the completion of 5', 3' RACE.

Spatial distribution of TPS in various tissues of C. sapidus Tissues were collected from male and female crabs at intermolt stage after they were anesthetized on ice as follows: eyestalk, brain, thoracic ganglion, antennal gland, gill, hindgut, heart, chelae muscle, hypodermis, testis or ovary, hepatopancreas, and Y-organ. Total RNAs were extracted using TRIzol $^{\oplus}$ (Invitrogen) and quantified with a NanoDrop 1000 (Thermo Scientific). After treatment with DNase I to eliminate genomic DNA contamination, one $\mu \mathrm{g}$ of total RNAs were used for the first cDNA synthesis with MMLV and random hexamers (Promega). Samples of cDNAs (each $12.5 \mathrm{ng}$ ) were amplified with a combination of primers: forward, 5'ATGTTGGTGGAACACAATTC AAGGAC3' and reverse, 5' TACAGAAGAGTCTCGGTAGAATGCA for TPS. Arginine kinase, a reference gene, was amplified using the same primers as described [27]. The PCR conditions were as follows: initial denaturation at $94^{\circ} \mathrm{C}$ for $2.5 \mathrm{~min}, 35$ cycles at $94^{\circ} \mathrm{C}$ for $20 \mathrm{sec}, 60^{\circ} \mathrm{C}$ for $20 \mathrm{sec}, 70^{\circ} \mathrm{C}$ for $30 \mathrm{sec} \mathrm{sec}$, and final step at $70^{\circ} \mathrm{C}$ for 5 min. PCR products were visualized by staining with ethidium bromide after electrophoresis on a $1.5 \%$ agarose gel.

\section{Lipopolysaccharide challenge}

Prior to the injection of LPS or saline, $100 \mu \mathrm{l}$ of hemolymph was withdrawn from juvenile animals (70-90 mm, carapace width) as described [27] to establish the resting levels of glucose and trehalose in hemocytes. Animals in

Table I: The list of primer sequences that was used for cloning of TPS gene and QRT-PCR

\begin{tabular}{ll}
\hline & Primer sequences (5'-3') \\
\hline TPS dRI & TCDCCRGCDCCRGCRAADGG \\
TPS dR2 & ATYTGRCARGCSACRAAYTC \\
TPS 3dFI & TTYGAYTCYTAYTAYAAYGG \\
TPS 3dF2 & TTYTGGCCNYTNTTYCAYTCYATGCC \\
TPSFI & ATGCCTGACAGAGCAACATTTCAG \\
TPSF2 (=QFI) & ATGTTGGTGGAACACAATTCAAGGAC \\
TPSRI & TACAGAAGAGTCTCGGTAGAATGCA \\
TPSR2(=QR) & CTTTGTATAATCTAACCGATCCACTC \\
TPSR3 & GCACGGAGTCTGGGTGGCTCTCA
\end{tabular}

' $d$ ' represents degenerate primers. Two forward primers of TPS FI and F2 were used for 3' RACE and three of TPSRI, R2, and R3 were for 5'RACE. Primers of QFI and QRI were used for QRT-PCR analysis. the test group received $1 \mu \mathrm{g}$ LPS (E. coli 0111:B4, Sigma) in $100 \mu \mathrm{l}$ crustacean saline, while control animals received $100 \mu \mathrm{l}$ saline alone. $24 \mathrm{~h}$ after injection, $500 \mu \mathrm{l}$ of hemolymph were withdrawn in an anticoagulant at a ratio of 1:1 and immediately centrifuged as described above. The hemocytes were re-suspended in ice cold DEPC treated PBS or Tris buffered saline and homogenized. Half of the samples were dedicated for estimating glucose, trehalose, and TPS activity, while the rest were used for RNA extraction as described above. Hemocyte protein was determined using BioRad DC protein assay (BioRad).

\section{Quantitative RT-PCR analysis (QRT-PCR)}

The extraction and quantification procedures of total RNA of hemocytes and cDNA synthesis were stated in Chung and Zmora [27]. Standards for QRT-PCR were produced as described [25]. Sample cDNAs (12.5 - $25 \mathrm{ng})$ were analyzed for the estimation of the expressions of TPS using primers of QF: 5' ATGTTGGTGGAACACAATTCAAGGA C3' and QR: 5' CTTTGTATAATCTAACCGATCCACTC3' and the data were calculated as copy number/ $\mu \mathrm{g}$ of total RNA of hemocytes. The level of hemocyte trehalase (Treh, GenBank accession no. EU679407) was quantified using the following primers, QF: 5' GCAGAGAGTGGATGGG A3' and QR: 5' CCCTGACAGCAGCAAGCCCTCA3'. The expression levels of TPS and Treh were represented as copy number/ $\mu \mathrm{g}$ total RNA as described [26].

\section{Estimation of glucose and trehalose in hemocytes}

Glucose levels in hemocytes were determined using glucose oxidase/peroxidase assay (Sigma) as described [28]. Trehalose concentration in hemocytes was estimated by subtracting the amount of glucose from the values determined by anthrone assay, as this assay measures both sugars [29]. Trehalose (Sigma) was used for the standard of anthrone assay. The results were presented as $\mu \mathrm{g}$ glucose or $\mathrm{mg}$ trehalose/mg protein in hemocyte extracts.

\section{Two-step TPS activity assay}

TPS activity in hemocytes was estimated using a modified procedure that was previously described $[30,31]$. For the first step of the synthesis of trehalose 6-phospate, $100 \mu \mathrm{g}$ of extracts from hemocytes was incubated in $200 \mu \mathrm{l}$ final volume of the first reaction mixture containing $50 \mathrm{mM}$ HEPES buffer (pH 7.1), 5 mM UDP-glucose (UDPG), 10 $\mathrm{mM}$ glucose-6-phosphate, and $12.5 \mathrm{mM} \mathrm{MgCl}_{2}$ at $35^{\circ} \mathrm{C}$ for $30 \mathrm{~min}$. In controls, glucose-6-phosphate was omitted. The reactions were terminated with heat treatment at $100^{\circ} \mathrm{C}$ for $5 \mathrm{~min}$ and were centrifuged at $13,000 \mathrm{rpm}$ for $5 \mathrm{~min}$ at room temperature. For the second step, the supernatants $(150 \mu \mathrm{l})$ were further incubated at $35^{\circ} \mathrm{C}$ for $10 \mathrm{~min}$ in the following reaction mixture $(150 \mathrm{mM}$ HEPES buffer, $\mathrm{pH}$ 7.6, $2 \mathrm{mM}$ phosphoenolpyruvate, 0.5 $\mathrm{mM} \mathrm{NADH}, 5 \mathrm{U}$ lactic dehydrogenase and $5 \mathrm{U}$ pyruvate kinase). Samples were cooled on ice for $5 \mathrm{~min}$ and briefly 
centrifuged for 13,000 rpm for $1 \mathrm{~min}$. $100 \mu \mathrm{l}$ of the supernatant was placed into a 96 well plate, and the absorbance was measured at $340 \mathrm{~nm}$ (Spectra M5, Molecular Device). Known concentrations of UDP at 1000, 500, 250, 125, and $62.5 \mathrm{nmol}$ were treated as above and served for a standard curve. TPS activity was calculated per $\mu$ mol UDP/ $\mathrm{h} / \mathrm{mg}$ hemocyte protein.

\section{Trehalose 6-phosphate phosphatase (TPP) assay}

In order to test the functionality of TPP domain of CasHemoTPS, the hemocytes were extracted in Tris-buffered saline and TPP enzyme activity was measured by following the procedure described in Klutts et al. [32]. The activity was calculated as $\mu \mathrm{mol}[\mathrm{Pi}] / \mathrm{h} / \mathrm{mg}$ hemocyte protein.

\section{Estimation of TPS activity in hemocytes during molt cycle} Hemolymph samples were collected from animals at molt stages as described [33] and assayed as described above. Hemocytes homogenized in $200 \mu$ l of ice cold PBS by sonication (Branson); the extracts were centrifuged at 14,000 rpm for $10 \mathrm{~min}$ at $4^{\circ} \mathrm{C}$; and, the supernatants were collected for the estimation of protein concentration as described above.

\section{Statistical analysis}

Statistical significance was determined at $\mathrm{P}<0.05$ using GraphPad InStat 3 program (GraphPad Software, Inc).

\section{Abbreviations}

TPS: trehalose 6-phosphate synthase gene; Treh: trehalase

\section{Competing interests}

The author declares that they have no competing interests.

\section{Authors' contributions}

JSC carried out the molecular cloning of TPS gene, TPS and TPP bioassays, and the bioassays.

\section{Acknowledgements}

JSC thanks O. Zmora and the personnel in the blue crab hatchery program for the juvenile crabs and S. Rogers and the ARC personnel for maintaining the water quality of the re-circulation system. This article is contribution no. 08-193 of the Center of Marine Biotechnology (University of Maryland Biotechnology Institute, Baltimore, MD, USA), and the work is supported by a program grant (NA17FU2841) from NOAA Chesapeake Bay Office to the Blue Crab Advanced Research Consortium.

\section{References}

I. Clegg JS: The origin of trehalose and its significance during the formation of encysted dormant embryos of Artemina salina. Comparative Biochemistry and Physiology 1965, I 4: | 35- |43.

2. Goyal K, Browne JA, Burnell AM, Tunnacliffe A: Dehydrationinduced tps gene transcripts from an anhydrobiotic nematode contain novel spliced leaders and encode atypical GT20 family proteins. Biochemie 2005, 87:565-574.
3. Sakurai M, Furuki T, Akao A, Tanaka D, Nakahara Y, Kikawada T, Watanabe M, Okuda T: Vitrification is essential for anhydrobiosis in an African chironomid, Polypedilum vanderplanki. Proceedings of the National Academy of Sciences USA 2008, 105:5093-5098.

4. Becker A, Schloder P, Steele JE, Wegener G: The regulation of trehalose metabolism in insects. Experientia 1996, 52(5):433-439.

5. Wyatt GR, Kalf GF: The chemistry of insect hemolymph. Trehalose and other carbohydrates. Journal of General Physiology 1957, 40:833-846.

6. Zoltowska K, Lopieniska-Biernat E: Content of glycogen and trehalose and activity of $\alpha$-amylase and trehalase in Galleria mellonella larvae infected with entomophthogenic nematodes Steinemema affinis and S. feltiae. Wiad Parazytol 2006, 52(2): $103-107$.

7. Chen Q, Ma E, Behar KL, Xu T, Haddad GG: Role trehalose phosphate synthase in anoxia tolerance and development in Drosophila melanogaster. Journal of Biological Chemistry 2002, 277:3274-3279.

8. Chang ES, Keller R, Chang SA: Quantification of crustacean hyperglycemic hormone by ELISA in hemolymph of the lobster, Homarus americanus, following various stresses. General and Comparative Endocrinology 1998, II I :359-366.

9. Chung JS, Webster SG: Dynamics of in vivo release of moltinhibiting hormone and crustacean hyperglycemic hormone in the shore crab, Carcinus maenas. Endocrinology 2005, | 46:5545-555।.

10. Johnston MA, Spencer Davies P, Elder HY: Possible hepatic function for crustacean blood cells. Nature 197I, 330:47I-472.

II. Keller R, Andrew EM: The site of action of the crustacean hyperglycemic hormone. General and Comparative Endocrinology 1973, 20:572-578.

12. Lorenzon S, Edomi P, Giulianini PG, Mettulio R, Ferrero EA: Variation of crustacean hyperglycemic hormone (cHH) level in the eyestalk and haemolymph of the shrimp Palaemon elegans following stress. Journal of Experimental Biology 2004, 207:4205-42।3.

13. Lorenzon S, Giulianini PG, Ferrero EA: Lipopolysaccharideinduced hyperglycemia is mediated by $\mathrm{CHH}$ release in crustaceans. General and Comparative Endocrinology 1997, 108:395-405.

14. Sedlmeier D: The role of hepatopancreatic glycogen in the action of the crustacean hyperglycemic hormone (CHH). Comparative Biochemistry and Physiology 1987, 87a:423-435.

15. Stentiford GD, Chang ES, Chang SA, Neil DM: Carbohydrate dynamics and the crustacean hyperglycemic hormone (CHH) effects of parasitic infection in Norway lobsters (Nephrops norvegicus). General and Comparative Endocrinology 200 I, | 2 |: | 3-22.

16. Issartel J, Renault D, Voituron Y, Bouchereau A, Vernon P, Hervant $\mathrm{F}$ : Metabolic responses to cold in subterrranean crustaceans. Journal of Experimental Biology 2005, 208:2923-2929.

17. Siebers D, Lucu C, Sperling K-R, Eberlein K: Kinetics of osmoregulation in the crab Carcinus maenas. Marine Biology 1972, 17:291-303.

18. Lipcius RN, Seitz RD, Seebo MS, Colon-Carrion D: Density, abundance and survival of the blue crab in seagrass and unstructural salt marsh nurseries of Chesapeake Bay. Journal of Experimental Marine Biology and Ecology 2005, 31 9:69-80.

19. Dereeper A, Guignon V, Blanc G, Audic S, Buffet S, Chevenet F, Dufayard JF, Guindon S, Lefort V, Lescot M, et al.: Phyologeny.fr: robust phylogenetic analysis for the non-specialist. Nucleic Acids Research 2008, 36:W465-459.

20. Mitsumasu K, Azuma M, Niimi T, Tamashita O, Yaginuma T: Membrane-penetrating trehalase from silkworm Bombyx mori. Molecular cloning and localization in larval midgut. Insect Molecular Biology 2005, 14:50 I-508.

21. Waytt GR, Kalf GF: The chemistry of insect hemolymph. Trehalose and other carbohydrates. Journal of General Physiology 1957, 40:833-846.

22. Chung JS, Dircksen H, Webster SG: A remarkable, precisely timed release of hyperglycemic hormone from endocrine cells in the guts is associated with ecdysis in the green crab, Carcinus maenas. Proceedings of the National Academy of Sciences USA 1999, 96:13103-13107.

23. Neufeld DS, Cameron JN: Mechanism of the net water uptake in molting blue crabs (Callinectes sapidus) acclimated to high and low salinities. Journal of Experimental Biology 1994, I88: I I-23. 
24. Tang B, Chen X, Liu Y, Tian H, Liu J, Hu J, Xu W, Zhang W: Characterization and expression patterns of a membrane-bound trehalase from Spodoptera exigua. BMC Molecular Biology 2008, 9:5I.

25. Chung JS, Webster SG: Moult cycle-related changes in biological activity of moult-inhibiting hormone (MIH) and crustacean hyperglycaemic hormone (CHH) in the crab, Carcinus maenas. European Journal of Biochemistry 2003, 270:3280-3288.

26. Chung JS, Wilcockson DC, Zmora N, Zohar Y, Dircksen H, Webster SG: Identification and developmental expression of mRNA encoding crustacean cardioactive peptide (CCAP) in decapod crustaceans. Journal of Experimental Biology 2006, 209:3862-3872.

27. Chung JS, Zmora N: Functional studies of crustacean hyperglycemic hormone (CHHs) of the blue crab, Callinectes sapidus - the expression and release of $\mathrm{CHH}$ in eyestalk and pericardial organ in response to environmental stress. FEBS J 2008, 275(4):693-704.

28. Webster SG: Measurement of crustacean hyperglycaemic hormone levels in the edible crab Cancer pagurus during emersion stress. Journal of Experimental Biology 1996, 199: 1579-1585.

29. Roe $\mathrm{JH}$ : The determination of sugar in blood and sinal fluid with anthrone reagent. Journal of Biological Chemistry 1955, 21 2:335-343.

30. Hottiger T, Schmutz P, Wiemken A: Heat-induced accumulation and futile cycling of trehalose in Saccharomyces cerevisiae. Journal of Bacteriology 1987, 169:55 I8-5522.

31. Valenzuela-Soto EM, Marquez-Escalante JA, Iturriaga G, FiguerosaSoto CG: Trehalose 6-phosphate synthase from Selaginella lepidophylla: purification and properties. Biochemical and Biophysical Research Communications 2004, 3 I 3:3 I4-3I 9.

32. Klutts S, Pastuszak I, Koroth V, Edavana K, Thampi P, Pan YT, Abraham EC, Carroll D, Elbein AD: Purification, cloning, expression, and properties of Mycobacterial trehalose-phosphate phosphatase. Journal of Biological Chemistry 2003, 278:2093-2100.

33. Drach P, Tchernigovtzeff C: Sur la methode de determination des stades d'intermue et son application-generale aux Crustaces. Vie et milieu series A Biol 1967, 18:595-610.

Publish with Bio Med Central and every scientist can read your work free of charge

"BioMed Central will be the most significant development for disseminating the results of biomedical research in our lifetime. "

Sir Paul Nurse, Cancer Research UK

Your research papers will be:

- available free of charge to the entire biomedical community

- peer reviewed and published immediately upon acceptance

- cited in PubMed and archived on PubMed Central

- yours - you keep the copyright

Submit your manuscript here:

http://www.biomedcentral.com/info/publishing_adv.asp
BioMedcentral 